\title{
Increase in ovulation rate after immunization of Merino ewes with a fraction of bovine follicular fluid containing inhibin activity
}

\author{
L. J. Cummins†, T. O’Shea, S. A. R. Al-Obaidi, B. M. Bindon* and \\ J. K. Findlay \\ Department of Physiology, University of New England, Armidale, New South Wales 2351; \\ ${ }^{*}$ C.S.I.R.O., Division of Animal Production, Armidale, New South Wales 2350; and \\ $\dagger$ Medical Research Centre, Prince Henry's Hospital, Victoria 3004, Australia
}

\begin{abstract}
Summary. Affinity chromatography of bovine follicular fluid using Matrix gel Red A resulted in a 20 -fold increase in inhibin-like specific activity assessed in a mouse ovulation inhibition test system. When this material was emulsified with Freund's adjuvant and injected into adult Merino ewes their mean ovulation rate was increased from 1.2 to $2.3(P<0.01)$. Follicles of diameter $\geqslant 3.5 \mathrm{~mm}$ and $2-3.4 \mathrm{~mm}$ were also increased ( 4.33 vs 2.25 and 5.39 vs 2.44 per ewe respectively). The ovulation rate response was variable and transient. Length of oestrous cycles, number of granulosa cells per follicle and seasonal oestrous patterns were not affected. Plasma from the immunized ewes contained antibodies to the immunogen and reversed the ovulationinhibiting effects of bovine follicular fluid in mice.
\end{abstract}

\section{Introduction}

Inhibin, as defined by its capacity in various species to suppress plasma follicle-stimulating hormone (FSH) specifically with little or no effect on plasma luteinizing hormone ( $\mathrm{LH}$ ) concentrations (Davies, Main \& Setchell, 1978; de Jong, 1979; Franchimont et al., 1979; Channing, Anderson, Hoover, Gagliano \& Hodgen, 1981; Cummins, O’Shea, Bindon, Lee \& Findlay, 1983), is a component of ovarian feedback on pituitary function. It might therefore be expected to play a role in the regulation of ovulation rate.

The hypothesis in the present experiments was that successful immunization of sheep with an inhibin-enriched preparation would neutralize the effects of endogenous inhibin, increase plasma FSH concentration and consequently increase ovulation rate. These attempts to immunize ewes were encouraged by reports that rabbits immunized with partly purified inhibin from various sources had increased FSH levels with no change in LH (Franchimont, Chari, Hagelstein \& Duraiswami, 1975; Franchimont et al., 1979). The previous demonstrations that charcoal-treated follicular fluid could delay onset of oestrus and ovulation in sheep (Miller, Critser, Rowe \& Ginther, 1979; O'Shea, Cummins, Lutjen \& Bindon, 1980) and suppress ovulation in mice (Cummins \& O'Shea, 1981), presumably due to the selective inhibition of plasma FSH, also provided some basis for these investigations. Bovine follicular fluid (bFF) was used in the sheep because a preliminary experiment using an antigen based on a partly purified inhibin-like fraction from ovine follicular fluid was unsuccessful.

†Present address: Department of Agriculture, Pastoral Research Institute, Hamilton, Victoria 3300, Australia. 


\section{Materials and Methods}

Animals. Thirty-six mixed age Merino ewes were grazed at pasture with periodic grain supplementation. Oestrous behaviour was detected by running vasectomized rams, fitted with harnesses and crayons, with the ewes and examining the ewes at least weekly.

The number of corpora lutea (CL) was measured using laparoscopy and ovulation rate was derived as $\mathrm{CL} / \mathrm{ewe}$. When laparoscopic examination followed an injection of immunogen, the interval was $2-3$ weeks.

Preparation of an inhibin-enriched fraction from follicular fluid. Ovaries of cows were collected on ice at abattoirs and bFF was harvested on the day of collection, after overnight storage at $4^{\circ} \mathrm{C}$, or after storage at $-15^{\circ} \mathrm{C}$ for a few days. The follicular fluid was aspirated from all visible follicles, excluding follicles assessed subjectively as being cystic, through a 19-gauge needle and stored at $-15^{\circ} \mathrm{C}$. Partial purification was achieved as described by Jansen, Steenbergen, de Jong \& van der Molen (1981) using affinity chromatography on Matrix gel Red A (Reactive Red 120; Sigma, St Louis, MO, U.S.A.). A $2.6 \mathrm{~cm}$ diameter column was packed to a bed height of about $34 \mathrm{~cm}$ with $200 \mathrm{ml}$ of gel and equilibrated with buffer $\mathrm{A}(0.35 \mathrm{M}-\mathrm{KCl}, 1 \mathrm{M}$-urea in $25 \mathrm{~mm}$-Tris at $\mathrm{pH} 7)$. Thawed bFF was centrifuged at $18000 \mathrm{~g}$ for $1 \mathrm{~h}$ at $4^{\circ} \mathrm{C}$ to remove cellular debris and $60 \mathrm{ml}$ of supernatant were loaded on to the column. This was followed by $500 \mathrm{ml}$ of buffer $\mathrm{A}$ which eluted a large protein peak. Buffer B $(300 \mathrm{ml} ; 1 \cdot 2 \mathrm{M}-\mathrm{KCl}, 1 \mathrm{M}$-urea in $25 \mathrm{~mm}$ Tris at $\mathrm{pH} 7)$ was then used to elute the second peak which contained inhibin activity purified 20 -fold over the starting material (Jansen et al., 1981). The column was regenerated with $1 \mathrm{M}-\mathrm{NaCl}$.

Ovulation-inhibition test for inhibin-like activity in mice. Biological activity in the fractions of bFF was monitored by measuring the inhibition of hCG-induced ovulation in pregnant mice of the QS strain (Cummins \& O'Shea, 1981). Pregnant mice received test treatments by s.c. injection at 09:00 h on Day 5 of pregnancy (detection of copulatory plug = Day 1) and ovulation was induced by 10 i.u. hCG (Chorulon, Intervet, Sydney, Australia) s.c. at 18:00 h on Day 5. The mice were killed on Day 6 between 10:00 and 13:00 $\mathrm{h}$ and ovulation determined by counting the ova removed from the ampulla. In this bioassay parallel dose response lines were observed for ovine and bovine follicular fluid and partly purified inhibin. Linear decreases in ovulation rate were recorded for doses of bFF in the range 12.5 to $200 \mu \mathrm{l}$. Index of precision values $(\lambda)$ of between 0.13 and 0.36 were obtained in tests with 6-10 mice per dose/treatment subclass. The test cannot be described as being specific for inhibin since no purified form of this substance existed at the time of the investigations. However, the test does appear to depend on endogenous FSH suppression by the components of follicular fluid since the ovulation inhibition by bFF can be readily reversed by injections of NIH-FSH-S8 but not by NIH-LH-S16 (Cummins, 1983).

Immunization of ewes. Each dose of immunogen contained $2.25 \mathrm{mg}$ partly purified inhibin protein, $0.8 \mathrm{ml}$ Freund's complete adjuvant (Commonwealth Serum Laboratories, Sydney, Australia), and $0.2 \mathrm{ml} 1 \%$ Tween 80 , made up to $2.4 \mathrm{ml}$ with distilled water. The mixture was mechanically emulsified and kept on ice while the flock was being injected. Each treatment ewe was injected with partly purified inhibin (referred to as inhibin for convenience), $0.8 \mathrm{ml} \mathrm{im}$. in each hind leg and $0.8 \mathrm{ml}$ s.c. divided between five sites along the back. Control ewes were injected similarly with a mixture of $2.25 \mathrm{mg}$ bovine serum albumin (Sigma), adjuvant and Tween 80 . Treatments began on 5 April 1981 and were repeated at monthly intervals during this and subsequent breeding seasons as shown in Fig. 2.

Plasma samples and neutralization experiments. Blood samples were taken by jugular venepuncture into heparinized containers. Steroids were removed from plasma for immunoneutralization experiments (e.g. progesterone to $3.5 \mathrm{ng} / \mathrm{ml}$, the same value as a solvent blank) by adding $50 \mathrm{mg}$ dextran-coated charcoal to each $1 \mathrm{ml}$ and shaking intermittently for $30 \mathrm{~min}$ at room temperature $\left(23^{\circ} \mathrm{C}\right)$. The charcoal was then removed by centrifugation at $18000 \mathrm{~g}$ for $1 \mathrm{~h}$ at $4^{\circ} \mathrm{C}$ 
and filtration (Whatman, No. 42 paper) of the supernatant. Plasma was tested for its ability to neutralize the ovulation inhibitory effects of bFF in mice.

Antigen-antibody precipitation was examined by an Ouchterlony plate technique using sodium azide agar plus $2 \% \mathrm{NaCl}$ in complement fixation testing medium. Plasma samples from both groups of immunized ewes were run against BSA, bFF and the partly purified inhibin for $18 \mathrm{~h}$ at $37^{\circ} \mathrm{C}$ and then inspected for the development of precipitin lines.

Ovarian parameters. The oestrous cycles of the ewes were synchronized by insertion of medroxyprogesterone acetate vaginal sponges (Repromap-MAP, Upjohn, N.S.W., Australia) from 19 April 1983 to 1 May 1983. The ewes were ovariectomized on 17 May 1983 under general anaesthesia (Pentothal: Abbott Laboratories, Sydney, Australia) and all follicles $>2 \mathrm{~mm}$ diameter were dissected out. Follicular volume was determined from follicular diameter as described by Tsonis $e t$ al. (1983). After follicular fluid was recovered from follicles with diameter $\geqslant 3.5 \mathrm{~mm}$, their granulosa cells were harvested by scraping with a wire loop in calcium- and magnesium-free phosphate-buffered saline. Samples from the granulosa cell suspensions were diluted in a balanced electrolyte solution (Isoton II, Coulter Electronics, Luton, U.K.) and counted with a Coulter Counter calibrated by also counting the first 30 samples in a haemocytometer. Corpora lutea were dissected out and weighed.

Statistical analysis. The ewes were randomized within subsets based on age and weight into treatment (mean \pm s.e., $39.1 \pm 1.0 \mathrm{~kg}$ ) and control $(38.8 \pm 0.6 \mathrm{~kg})$ groups. Table VI in Fisher \& Yates (1957) was used to test the significance of the increased ovulation rate of the treated ewes. Other data were examined by means of $\chi^{2}$ and $t$ tests.

\section{Results}

\section{Detection of antibody formation}

Immunization of ewes at monthly intervals with partly purified inhibin resulted in the development of typical antigen-antibody precipitation lines in the agar gel. When plasma samples of 16 immunized ewes were collected in May 1981 (after 2 injections) and tested, a broad zone of precipitation made up of several lines was evident. In the June 1981 samples (after 3 injections) of plasma from inhibin-immunized ewes showed 2 or 3 precipitin lines against bFF and 2 or 3 (less heavy) against partly purified inhibin, whereas plasma from ewes immunized with albumin (control ewes) showed 1 or 2 precipitin lines against bFF and none against partly purified inhibin (Fig. 1). When plasma samples from the inhibin-immunized ewes were serially diluted the precipitin lines against partly purified inhibin showed no differences related to the ovulatory responses of individual ewes.

\section{Immunoneutralization effects in mice}

Data are presented in Table 1. Partly purified inhibin alone and in combination with plasma from the control ewes resulted in significantly $(P<0.05)$ lower ovulation rates than in the control mice treated with plasma. Mice injected with partly purified inhibin plus plasma from inhibinimmunized ewes did not differ in ovulation rate from the control mice.

\section{Ovulation rate of immunized ewes}

Mean ovulation rates during 1981, 1982 and 1983 for the immunized and control ewes are summarized in Fig. 2. After the immunization regimen in each breeding season (at times indicated 


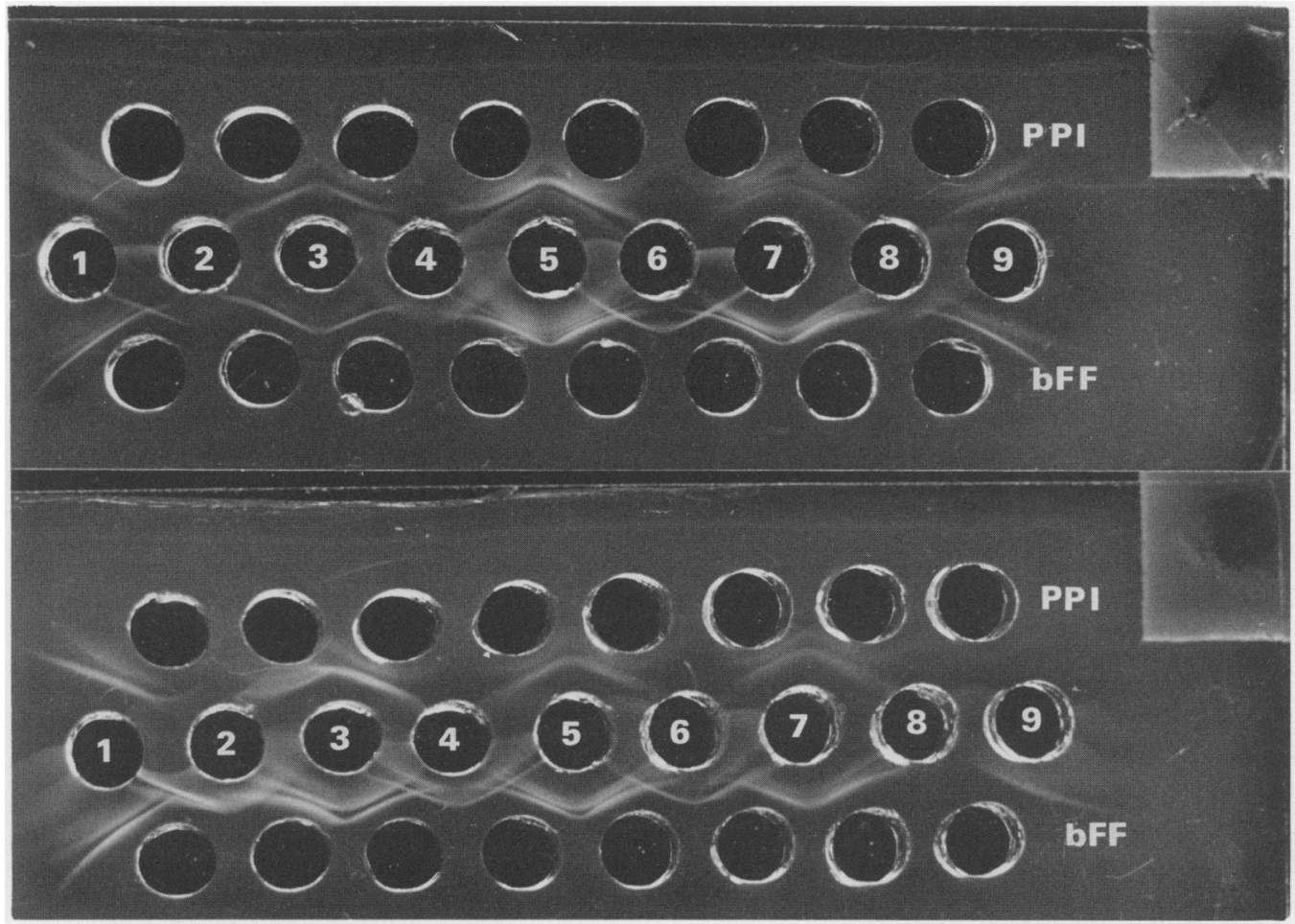

Fig. 1. Antigen-antibody precipitation in sodium azide agar plus $2 \% \mathrm{NaCl}$ in complement fixation-testing medium. In each panel (representing samples from June 1981), one row of wells contained bovine follicular fluid (bFF), one row contained the inhibin-enriched fraction from bFF (PPI) and in the middle row Wells 1, 3, 5, 7 and 9 contained plasma from ewes immunized against partly purified inhibin and Wells $2,4,6$ and 8 contained plasma from ewes immunized against bovine serum albumin.

Table 1. The effects of plasma collected from ewes immunized against partly purified inhibin on the hCG-induced ovulation rate in mice at Day 6 of pregnancy (10 mice per group)

\begin{tabular}{|c|c|c|}
\hline \multirow[t]{2}{*}{ Treatment on Day 5 of pr } & \multirow[b]{2}{*}{$18: 00 \mathrm{~h}$} & \multirow{2}{*}{$\begin{array}{l}\text { Ovulation rate } \\
\text { (mean } \pm \text { s.e.m.) }\end{array}$} \\
\hline & & \\
\hline Bovine plasma $(0.2 \mathrm{ml})$ & 10 i.u. hCG & $8 \cdot 8 \pm 1 \cdot 5^{\mathrm{a}}$ \\
\hline Inhibin-enriched fraction $(0.2 \mathrm{ml})$ & 10 i.u. hCG & $4 \cdot 3 \pm 1 \cdot 0^{\mathrm{bc}}$ \\
\hline \multicolumn{3}{|l|}{ Inhibin-enriched fraction $(0.2 \mathrm{ml})$} \\
\hline+ plasma from immunized ewes $(0.2 \mathrm{ml})$ & 10 i.u. hCG & $6 \cdot 7 \pm 1 \cdot 4^{\mathrm{ab}}$ \\
\hline \multicolumn{3}{|l|}{ Inhibin-enriched fraction $(0.2 \mathrm{ml})$} \\
\hline+ plasma from control ewes $(0.2 \mathrm{ml})$ & 10 i.u. hCG & $3 \cdot 0 \pm 0 \cdot 5^{\mathrm{c}}$ \\
\hline
\end{tabular}

Means with different superscripts differ $(P<0.05 ;$ Duncan's multiple range test $)$.

in Fig. 2) ovulation rate was greater in the inhibin-immunized ewes. This increase was less marked during 1981 but significantly more inhibin-immunized ewes had more than one CL in June (7 of 17 immunized ewes compared with 2 of 18 control ewes, $\chi^{2}=4.43, P<0.05$ ), and July 1981 ( 7 of 17 compared with 1 of $18, \chi^{2}=4.95, P<0.05$ ), at which time the maximum ovulation rate reached 6 for inhibin-immunized and 2 for control ewes. 


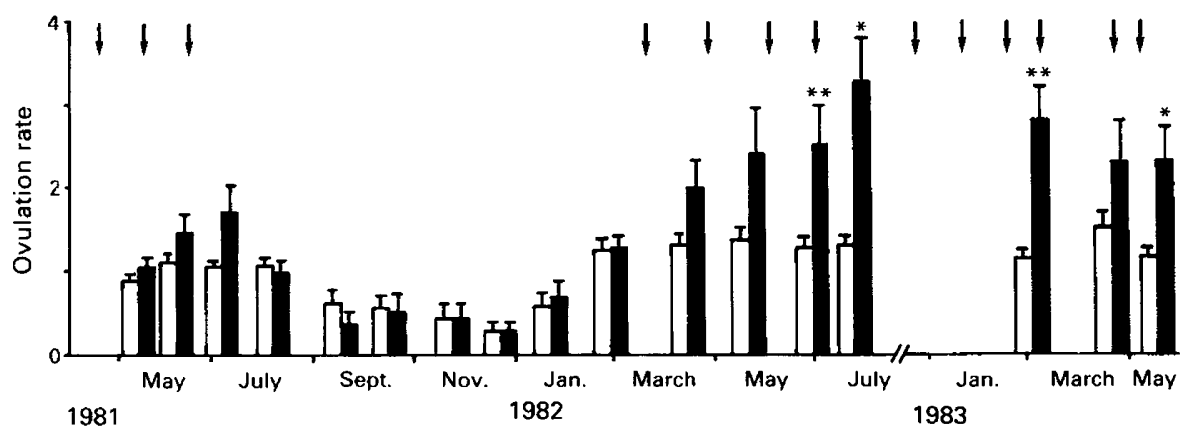

Fig. 2. Ovulation rate in Merino ewes immunized with bovine serum albumin ( $\square$ ) or an inhibin-enriched fraction from bovine follicular fluid $(\square)$. Values are means \pm s.e.m. for 13-18 animals. Arrows indicate dates of immunization. ${ }^{*} P<0.05,{ }^{* *} P<0.01$.

High and significantly $(P<0.01)$ increased ovulation rates were recorded in 1982 and 1983 after re-immunization (Fig. 2). The ovulation rate in the inhibin-immunized ewes was very variable between ewes at any one observation and also within individual ewes at sequential laparoscopies. Some individual patterns are illustrated in Table 2. Two immunized ewes had no obvious change in their ovulation rate.

After re-immunization a significantly greater proportion of the ewes had more than one ovulation in June 1982 (14 of 17 compared with 5 of $17, \chi^{2}=7 \cdot 646, P<0.01$ ), July 1982 (14 of 17 compared with 4 of $\left.15, \chi^{2}=7.906, P<0.01\right)$ and March $(15$ of 17 compared with 2 of 13 , $\left.\chi^{2}=13.093, P<0.001\right)$ and May $\left(12\right.$ of 18 compared with 3 of $\left.16, \chi^{2}=6.064, P<0.02\right) 1983$.

Table 2. Patterns of ovulation rate in ewes at times when a response to immunization with an inhibinenriched fraction from bovine follicular fluid was observed

\begin{tabular}{|c|c|c|c|c|c|c|c|c|c|}
\hline & \multicolumn{3}{|c|}{1981} & \multicolumn{3}{|c|}{1982} & \multicolumn{3}{|c|}{1983} \\
\hline & June & July & April & May & June & July & March & April & May \\
\hline \multicolumn{10}{|c|}{ Control ewes } \\
\hline A & 1 & 1 & 1 & 1 & 1 & 1 & 1 & 1 & 1 \\
\hline $\mathbf{F}$ & 1 & 1 & 1 & 2 & 1 & 1 & 1 & 2 & 1 \\
\hline G & I & 2 & 2 & 2 & 2 & 2 & 1 & 2 & 1 \\
\hline B & I & 1 & 1 & 1 & 1 & 1 & 1 & 1 & 1 \\
\hline $\mathbf{K}$ & I & 1 & 1 & 1 & 1 & 1 & 1 & 1 & 1 \\
\hline \multicolumn{10}{|c|}{ Immunized ewes } \\
\hline $\mathrm{C}$ & 1 & 1 & 2 & 2 & 1 & 1 & 2 & 2 & 1 \\
\hline D & 2 & 1 & 2 & 3 & 4 & 4 & 2 & 2 & 1 \\
\hline $\mathbf{H}$ & 4 & 6 & 2 & $11-$ & 2 & 4 & 5 & 4 & 5 \\
\hline $\mathbf{M}$ & 2 & 1 & 7 & 2 & 2 & 5 & 2 & 2 & 1 \\
\hline $\mathbf{Z}$ & 0 & 1 & 2 & 3 & 5 & 8 & 7 & 9 & 4 \\
\hline
\end{tabular}

\section{Oestrous activity}

Over the 3 years, immunization with partly purified inhibin had no significant effect on seasonal changes seen in the proportion of ewes showing oestrus (Fig. 3) or ovulating. Onset of the breeding season was unaffected whether immunization was stopped well before its onset (1981-82) or was recommenced just before onset of cyclicity (1982-83). 


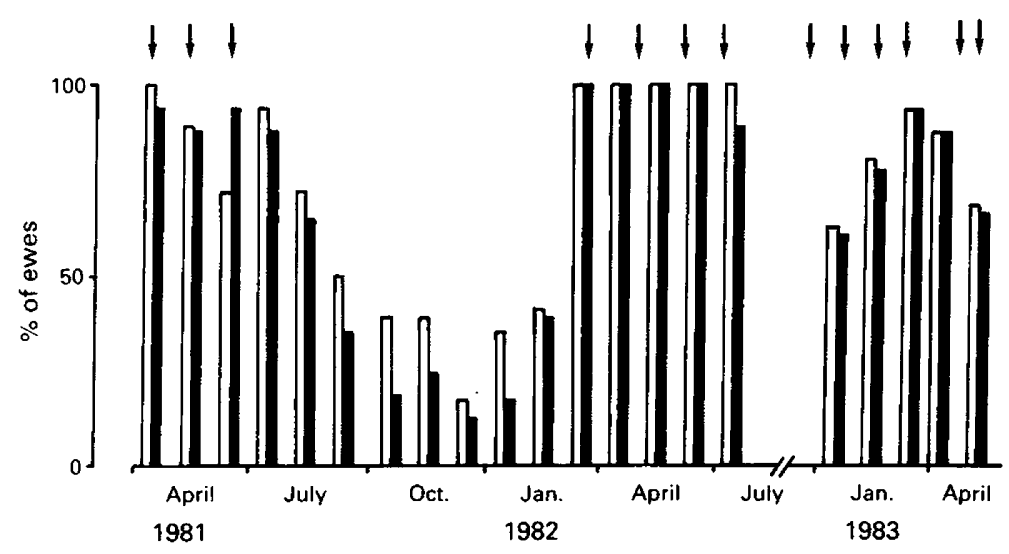

Fig. 3. Behavioural oestrus recorded during each month in Merino ewes immunized with bovine serum albumin $(\square)$ or an inhibin-enriched fraction from bovine follicular fluid ( $\square$ ). Arrows indicate times of immunization.

Oestrous cycle length was similar in both groups of sheep; e.g. in March 1982 the ewes were re-immunized and cycle lengths (mean \pm s.e.m.) before and after this treatment were $17.4 \pm 0.39$ and 17.6 \pm 0.27 days in 15 inhibin-immunized ewes and 17.4 \pm 0.21 and $17.5 \pm 0.22$ days in 16 control ewes.

\section{Ovarian parameters at ovariectomy}

Data obtained for CL and follicles are presented in Table 3. The increased number of CL in the inhibin-immunized ewes $(P<0.05)$ confirmed earlier data obtained by laparoscopy. The mean weight within the ewes of an individual CL was not significantly reduced but the total weight of CL per ewe was increased $(P<0.01)$ in the immunized ewes. The number of follicles between 2 and

Table 3. Ovarian characteristics in control Merino ewes and Merino ewes immunized against an inhibinenriched fraction from bovine follicular fluid

\begin{tabular}{|c|c|c|c|}
\hline & Control ewes & Immunized ewes & Significance \\
\hline No. of ewes & 16 & 18 & - \\
\hline Mean no. of $\mathrm{CL}$ per ewe & $1 \cdot 19 \pm 0 \cdot 10$ & $2.30 \pm 0.41$ & $P<0.05$ \\
\hline Mean (within ewe) CL wt (mg) & $509 \pm 30(16)$ & $491 \pm 53(18)$ & N.S. \\
\hline Mean total CL wt (mg/ewe) & $584 \pm 42(16)$ & $976 \pm 98(18)$ & $P<0.01$ \\
\hline $\begin{array}{l}\text { Follicles with diam. } 2-3.4 \mathrm{~mm} \\
\quad(\log [\text { no. }+1] / \text { ewe })\end{array}$ & $0.495 \pm 0.031(16)$ & $0.653 \pm 0.061(18)$ & $P<0.05$ \\
\hline $\begin{array}{l}\text { Follicles with diam. } \geqslant 3.5 \mathrm{~mm} \\
\quad(\log [\text { no. }+1] / \text { ewe })\end{array}$ & $0.503 \pm 0.043(16)$ & $0.714 \pm 0.072(18)$ & $P<0.02$ \\
\hline $\begin{array}{l}\text { Mean volume }(\mu \mathrm{l}) \text { of follicles of } \\
\text { diam. }\end{array}$ & & & \\
\hline $\begin{array}{l}\geqslant 3.5 \mathrm{~mm}\left(\log _{\mathrm{e}}[\mathrm{x}+1]\right) \\
\text { Mean no. of granulosa cells in }\end{array}$ & $3.55 \pm 0.08(36)$ & $3.43 \pm 0.04(76)$ & N.S. \\
\hline $\begin{array}{l}\text { follicles of diam. } \geqslant 3.5 \mathrm{~mm} \\
\left(\log _{\mathrm{e}} \text { no. } \times 10^{-6}\right)\end{array}$ & $2.89 \pm 0.09(36)$ & $2.94 \pm 0.07(76)$ & N.S. \\
\hline \multicolumn{4}{|c|}{$\begin{array}{l}\text { Regression of } \log _{e} \text { no. of granulosa } \\
\text { cells on } \log _{e} \text { follicle volume: }\end{array}$} \\
\hline Regression coefficient & $0.458(36)$ & $0.539(76)$ & \\
\hline Intercept & $12 \cdot 568$ & 11.669 & \\
\hline Slope & 0.517 & 0.813 & \\
\hline
\end{tabular}

Values are means \pm s.e.m. for the number of observations in parentheses. 
$3.5 \mathrm{~mm}$ diameter was significantly increased $(P<0.02)$ and there were more follicles of diameter $\geqslant 3.5 \mathrm{~mm}$ in the immunized ewes $(P<0.05)$. Within the follicles of diameter $\geqslant 3.5 \mathrm{~mm}$ there were no differences in the mean follicle size, the mean number of granulosa cells per follicle or in the relationship between number of granulosa cells per follicle and follicle volume (the latter summarized in the regression data in Table 3). At ovariectomy 4 of the 18 inhibin-immunized ewes had hyperstimulated ovaries as assessed by the appearance of multiple follicles and several luteinized follicles.

\section{Discussion}

It is clear that active immunization with a fraction from bovine follicular fluid containing inhibin activity altered the ovulation rate control system in the ewes, resulting in a substantial increase in ovulation rate. The response seen in the ovulation rate was short-lived in that it disappeared each time injections were stopped but returned each year after the sheep were reimmunized. In other experiments with a larger flock of sheep residual effects were still present in a few ewes after 1 year, but only when the ewes had had multiple immunizations (O'Shea et al., 1984). The lack of effect of immunization on seasonality and oestrous cycle length may be partly related to the short-lived nature of the response.

There was a large variation in the response to immunization, both between ewes and within an individual ewe at different times. This could be due to the impurity of the immunogen which contains several compounds including inhibin and albumin (Jansen et al., 1981; M. Sinosich, B. M. Bindon \& T. O'Shea, unpublished data). Henderson, Franchimont, Lecomte-Yerna, Hudson \& Ball (1984) have also reported an increase in ovulation rate after immunization of ewes with a similar material. Their results show little variability in response. This difference could be due to the small group size ( 4 ewes, examined 4 times) and the fact that in the present work Tween 80 was used in preparing the emulsion and this may have given variable degradation of the immunogen. Other less likely possibilities are breed differences and inclusion of the intramuscular route in the present study. The response in ovulation rate observed by Henderson et al. (1984) was more rapid but development of antibodies only occurred later. A physiological response after one injection of antigen is somewhat surprising given the apparent short-term nature of the response (O'Shea et al., 1984). In the present study there was obviously increased response with booster injections.

The mechanism by which ovulation rate is increased is not clear. The demonstration of precipitation lines in the agar gel diffusion test suggests that antibodies are being formed against the fraction of bovine follicular fluid. The fact that plasma from ewes immunized with this fraction can neutralize the effects of follicular fluid in the induced ovulation test system in mice confirms that the antibodies are directed against factors involved in determining ovulation rate. Because of the unavailability of pure inhibin, it has not been possible to test the specificity, titre and duration of an inhibin response in the immunized ewes. It is not possible to prove that the active immunogen is inhibin or that the effect is related to increased FSH in the immunized ewes. The ewes immunized in the present study had higher plasma FSH when this was assayed using the homologous NIADDK ovine FSH assay but this was not confirmed in a heterologous assay system (S. A. R. Al-Obaidi, B. M. Bindon, J. K. Findlay, M. H. Hillard \& T. O'Shea, unpublished data). Plasma FSH concentrations in ewes immunized by Henderson et al. (1984) were not elevated. However, after the immunized ewes described in the present studies had been ovariectomized they resisted the FSH-depressing effect of an inhibin-enriched fraction of follicular fluid (Al-Obaidi, Bindon, Hillard, O'Shea \& Piper, 1984). A similar response has been reported in monkeys with antisera to porcine follicular fluid (Channing, Tanabe, Turner and Hodgen, 1982). These results suggest that the immunized ewes contained antibodies to inhibin.

The increase in the number of follicles with diameter $>2 \mathrm{~mm}$, the increased luteal weight per ewe, and the slight increase in plasma progesterone concentrations with increased ovulation rate 
(S. A. R. Al-Obaidi, B. M. Bindon, M. A. Hillard \& T. O'Shea, unpublished results), are similar to those seen in ewes with increased ovulation rate as a result of treatment with PMSG (Bindon, Ch'ang \& Turner, 1971).

However, the ovarian characteristics of the inhibin-immunized ewes are different from those of profilic Booroola Merino ewes, which have smaller preovulatory follicles and fewer granulosa cells per follicle (Baird, Ralph, Seamark, Amato \& Bindon, 1982). The immunized ewes differ in that the follicle population is the same mean size as in control ewes and there is a greater number of larger follicles than in control ewes.

These studies show that active immunization of sheep with bovine follicular fluid preparations containing inhibin increase ovulation rate. Significant increases in litter size also result from this procedure (O’Shea et al., 1984).

We thank J. Sheedy and R. Nethery for technical assistance, and the Australian Meat Research Committee for financial support.

\section{References}

Al-Obaidi, S.A.R., Bindon, B.M., Hillard, M.H., O'Shea, T. \& Piper, L.R. (1984) Depression of FSH in ovariectomized ewes by bovine follicular fluid: Neutralization by serum from ewes immunized against partially purified bovine inhibin. Proc. Aust. Soc. Reprod. Biol. 16, 17, Abstr.

Baird, D.T., Ralph, M.M., Seamark, R.F., Amato, F. \& Bindon, B.M. (1982) Pre-ovulatory follicular activity and estrogen secretion of high (Booroola) and low fecundity Merino ewes. Proc. Aust. Soc. Reprod. Biol. 14, 83, Abstr.

Bindon, B.M., Ch'ang, T.S. \& Turner, H.N. (1971) Ovarian response to gonadotrophin by Merino ewes selected for fecundity. Aust. J. Agric. Res. 22, $809-820$.

Channing, C.P., Anderson, L.D., Hoover, D.J., Gagliano, P. \& Hodgen, G.D. (1981) Inhibitory effects of porcine follicular fluid on monkey serum FSH levels and follicular maturation. Biol. Reprod. 25, 885-903.

Channing, C.P., Tanabe, K., Turner, C.K. \& Hodgen, G.D. (1982) Antisera to porcine follicular fluid in monkeys: Neutralization of human and pig inhibin activity in vivo and in vitro. $J$. clin. Endocr. Metab. $55,481-486$.

Cummins, L.J. (1983) Ovarian function in the Booroola Merino: the role of ovarian inhibiting factors in the regulation of ovulation rate. $\mathrm{Ph} . \mathrm{D}$. thesis, University of New England, Armidale.

Cummins, L.J. \& O'Shea, T. (1981) Suppression of induced ovulation by inhibin. Proc. Aust. Soc. Reprod. Biol. 13, 35, Abstr.

Cummins, L.J., O'Shea, T., Bindon, B.M., Lee, V.W.K. \& Findlay, J.K. (1983) Ovarian inhibin content and sensitivity to inhibin in Booroola and control strain Merino ewes. J. Reprod. Fert. 67, 1-7.

Davies, R.V., Main, S.J. \& Setchell, B.P. (1978) Inhibin: Evidence for its existence, methods of bioassay and nature of the active material. Int. J. Androl. Suppl. 2, $102-114$.

de Jong, F. (1979) Inhibin - fact or artefact. Molec. cell. Endocr. 13, 1-10.
Fisher, R.A. \& Yates, F. (1957) Statistical Tables for Biological, Agricultural and Medical Research. Oliver and Boyd, Edinburgh.

Franchimont, P., Chari, S., Hagelstein, M.T. \& Duraiswami, S. (1975) Existence of a follicle stimulating hormone inhibiting fraction 'inhibin' in bull seminal plasma. Nature, Lond. 257, 402-404.

Franchimont, P., Verstraelen-Proyard, J., HazeeHagelstein, M.T., Renard, Ch., Demoulin, A., Bourguignon, J.P. \& Hustin, J. (1979) Inhibin: from concept to reality. Vitams Horm. 37, 243-302.

Henderson, K.M., Franchimont, P., Lecomte-Yerna, M.J., Hudson, N. \& Ball, K. (1984) Increase in ovulation rate after active immunization of sheep with inhibin partially purified from bovine follicular fluid. J. Endocr. 102, 304-309.

Jansen, E.H.J.M., Steenbergen, J., de Jong, F.H. \& van der Molen, H.J. (1981) The use of affinity matrices in the purification of inhibin from bovine follicular fluid. Molec. cell. Endocr. 21, 109-117.

Miller, K.F., Critser, J.K., Rowe, R.F. \& Ginther, O.J. (1979) Ovarian effects of bovine follicular fluid treatment in sheep and cattle. Biol. Reprod. 21, 537-544.

O'Shea, T., Cummins, L.J., Lutjen, P. \& Bindon, B.M. (1980) Some factors affecting the response of ewes to injection of follicular fluid. Proc. Aust. Soc. Reprod. Biol. 12, 63, Abstr.

O'Shea, T., Al-Obaidi, S.A.R., Bindon, B.M., Cummins, L.J., Findlay, J.K. \& Hillard, M.H. (1984) Increased ovulation rate in Merino ewes and advancement of puberty in Merino lambs immunized with a preparation enriched in inhibin. In Reproduction in Sheep, pp. 335-337. Eds D. R. Lindsay \& D. T. Pearce. Australian Academy Science, Canberra.

Tsonis, C.G., Quigg, H., Lee, V.W.K., Leversha, L., Trounson, A.O. \& Findlay, J.K. (1983) Inhibin in individual ovine follicles in relation to diameter and atresia. J. Reprod. Fert. 67, 83-90.

Received 16 August 1985 